\title{
ВПЛИВ ПРЕПАРАТУ L-АРГІНІНУ НА ЗМІНИ ПРОЦЕСІВ ПЕРОКСИДНОГО ОКИСНЕННЯ ЛІПІДІВ ТА АНТИОКСИДАНТНОЇ СИСТЕМИ В КРОВІ ЗА УМОВ КОМОРБІДНОЇ ПАТОЛОГІЇ - ІММОБІЛІЗАЦІЙНОГО СТРЕСУ ТА АДРЕНАЛІНОВОГО УШКОДЖЕННЯ МІОКАРДА
}

Вступ. Активація адренергічної і гіпоталамо-гіпофрізарно-адреналової систем призводить до виникнення стресорної тріади Сельє, першим компонентом якої є гіпертрофрія надниркових залоз із збільшенням синтезу ними глюкокортикоїдів та катехоламінів. Аргінін слугує необхідним компонентом для синтезу білків і багатьох біологічно важливих молекул, таких, як орнітин, пролін, поліаміни, креатин і агматин. Однак головна його роль в організмі людини - бути субстратом для синтезу оксиду азоту.

Mета дослідження - вивчити вплив препарату L-аргініну на зміни процесів пероксидного окиснення ліпідів та антиоксидантної системи, що виникають у крові білих щурів під впливом гострого іммобілізаційного стресу й адреналіну.

Методи дослідження. Дослід проводили на білих щурах-самцях лінії Вістар масою 180-200 г, яких було поділено на три групи по 10 тварин у кожній (дві дослідні та одну контрольну).

Результати й обговорення. Встановлено, що за умов поєднаної патології (іммобілізаційного стресу й адреналінового ушкодження міокарда) до лікування L-аргініном активність у крові показників антиоксидантної системи - каталази і супероксиддисмутази зменшувалася на 5-ту добу експерименту. Було відзначено збільшення рівня продуктів пероксидного окиснення ліпідів - дієнових кон'югатів та малонового діальдегіду проти контролю. Використання L-аргініну протягом 5-ти днів призвело до підвищення активності каталази (на 107,2 \%) і супероксиддисмутази (на 74,5%) відносно групи тварин з поєднаною патологією в експерименті (іммобілізаційним стресом і адреналіновим ушкодженням міокарда) до лікування, що свідчить про антиоксидантний вплив даного препарату. Застосування L-аргініну протягом 5-ти днів знизило рівень дієнових кон'югатів (на 80,16\%, p<0,05) та малонового діальдегіду (на 42,26 \%, p<0,05), що вказує на зменшення процесів пероксидного окиснення ліпідів.

Висновок. L-аргінін доцільно в подальшому і перспективно вивчати в експерименті та клініці з метою корекції метаболічних порушень за умов експериментального іммобілізаційного стресу й адреналінового ушкодження міокарда і розробки методичних рекомендацій.

КЛЮЧОВІ СЛОВА: пероксидне окиснення ліпідів; антиоксидантна система; іммобілізаційний стрес; адреналінове ушкодження міокарда; L-аргінін.

ВСТУП. Існування сучасної людини постійно супроводжують стресові реакції, пов'язані зі стрімким ритмом життя, складними взаємовідносинами в суспільстві, важкими соціальними фракторами тощо. Адаптаційні реакції, що виникають в організмі на тлі надмірного стресу, можуть сприяти виникненню та розвитку низки патологічних процесів [1-3]. Основою стресу $є$ активація стресореалізуючих систем організму: адренергічної і гіпоталамо-гіпофрізарно-адреналової [4]. Активація цих систем призводить до виникнення стресорної тріади Сельє, першим компонентом якої $€$ гіпертрофрія надниркових залоз із збільшенням синтезу ними глюкокорти(с) О. Б. Лис, М. С. Регеда, 2018. коїдів і катехоламінів [5]. Змінам, які відбуваються в надниркових залозах на тлі стресу, присвячено значну кількість робіт, тоді як вплив стресових реакцій на процеси пероксидного окиснення ліпідів та антиоксидантної системи в крові вивчали значно менше [6, 7]. За частотою перше місце серед захворювань в Україні займають хвороби системи кровообігу, тому детальне вивчення впливу стресу та адреналінового ушкодження міокарда - адреналінової міокардіодистрофії є пріоритетним напрямком науки [8].

Аргінін - умовно незамінна амінокислота. Фізіологічна потреба тканин і органів більшості ссавців у аргініні задовольняється його ендогенним синтезом та/або надходженням 3 їжею, 
однак для молодих особин і дорослих за умов стресу чи хвороби ця амінокислота стає есенціальною. Аргінін слугує необхідним компонентом для синтезу білків і багатьох біологічно важливих молекул, таких, як орнітин, пролін, поліаміни, креатин і агматин. Однак головна його роль в організмі людини - бути субстратом для синтезу оксиду азоту [9]. Доведено позитивну дію L-apгініну на стан ендотелію судин, вазодилатацію, активність сперматозоїдів та інші системи організму, але мало вивчено його вплив на показники пероксидного окиснення ліпідів та антиоксидантний захист за умов експериментального і патологічного стресу $[10,11]$.

Мета дослідження - вивчити вплив препарату L-аргініну на зміни процесів пероксидного окиснення ліпідів та антиоксидантної системи, що виникають у крові білих щурів під впливом гострого іммобілізаційного стресу й адреналіну.

МЕТОДИ ДОСЛІДЖЕННЯ. Дослід проводили на білих щурах-самцях лінії Вістар масою 180200 г, яких було поділено на три групи по 10 тварин у кожній (дві дослідні та одну контрольну). Щурів 1-ї дослідної групи піддавали тривалому іммобілізаційному стресу (3 год), вводили їм внутрішньочеревно 0,18 \% розчин адреналіну гідротартрату в дозі 1 мг/кг маси тіла (О. О. Маркова, 1998), виводили з експерименту на 5-ту добу до лікування. Тварин 2-ї дослідної групи піддавали тривалому іммобілізаційному стресу (3 год), вводили їм внутрішньочеревно адреналін у дозі 1 мг/кг маси тіла, L-аргінін у дозі 1,5 мг/кг маси тіла впродовж 5 днів (з 1-ї до 5-ї доби), виводили з експерименту на 5-ту добу. Щурам контрольної групи вводили внутрішньочеревно 0,9\% розчин $\mathrm{NaCl}$ у дозі 1 мг/кг маси тіла.

Усіх експериментальних тварин утримували в стандартних умовах віварію Львівського національного медичного університету імені Данила Галицького. Дослідження проведено $з$ додержанням науково-практичних рекомендацій 3 утримання лабораторних тварин і роботи з ними та положень Європейської конвенції про захист хребетних тварин, що використовуються для дослідних та інших наукових цілей (Страсбург, 1986). Тварин декапітували під легким тіопентал-натрієвим наркозом (внутрішньочеревне введення 50 мг/кг $1 \%$ розчину) і виводили 3 експерименту на 5-ту добу. В плазмі крові щурів 3 індукованим стресом і адреналіновим ушкодженням міокарда в їх поєднанні визначали активність каталази (КТ), супероксиддисмутази (СОД), дієнових кон'югатів (ДК) та малонового діальдегіду (МДА). Дані групи порівнювали 3 контрольною.
Активність КТ визначали за методом М. А. Королюк, Л. І. Іванової, І. Г. Майорової [12], СОД за методом В. С. Гуревич, К. Н. Конторщикова, Л. В. Шатиліної [13], концентрацію ДК - за методом В. С. Камишникова [14], МДА - за методом Р. А. Тимирбулатова, Є. М. Селезньова [15]. Іммобілізаційний стрес моделювали за методом П. Д. Горизонтова, О. І. Бєлоусова, М. І. Фетодова [16]. Адреналінове ушкодження міокарда відтворювали за методом О. О. Маркової [8]. Статистичне опрацювання одержаних даних здійснювали з використанням критерію Стьюдента [17].

РЕЗУЛЬТАТИ Й ОБГОВОРЕННЯ. За УМОВ поєднаної патології (іммобілізаційного стресу й адреналінового ушкодження міокарда) до лікування активність у крові показників антиоксидантної системи - КТ та СОД зменшувалася на 5-ту добу експерименту. Зокрема, активність КТ знизилась на 36,70 \% (p<0,05), СОД - на 31,06 \% $(p<0,05)$ порівняно 3 контрольною групою. Порівнявши результати дослідження тварин за умов іммобілізаційного стресу й адреналінового ушкодження міокарда після застосування препарату L-аргініну протягом 5-ти днів (2-га дослідна група), встановили, що активність у крові КТ підвищилась на 107,2 \% ( $<<0,05)$, СОД - на $74,50 \%(p<0,05)$ порівняно 3 1-ю дослідною групою до лікування. Ці зміни активності КТ та СОД детально показано на рисунках 1 і 2.

Концентрацію продуктів пероксидного окиснення ліпідів оцінювали за рівнем ДК та МДА в крові, який визначали на 5-ту добу після моделювання іммобілізаційного стресу й адреналінового ушкодження міокарда в щурів до лікування.

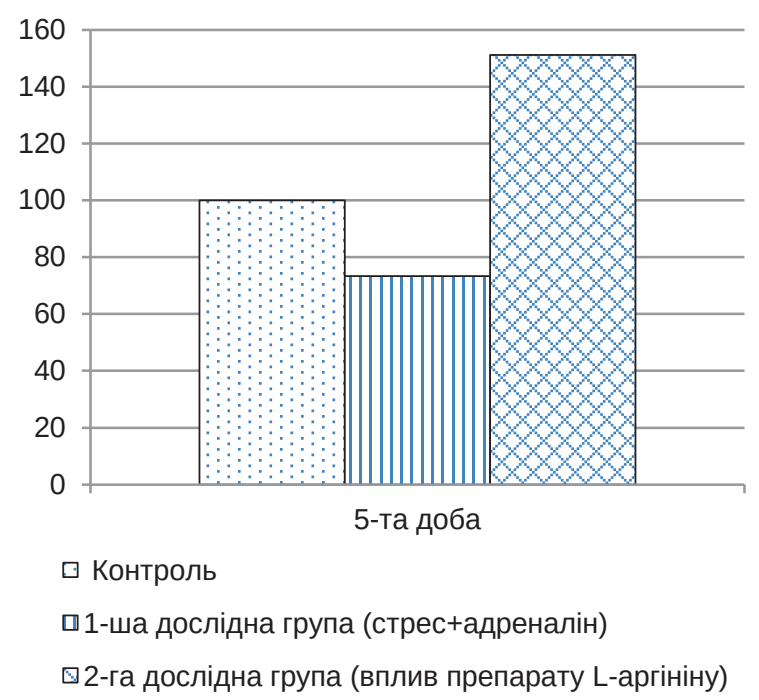

Рис. 1. Активність каталази в крові щурів при іммобілізаційному стресі та адреналіновому ушкодженні міокарда і вплив L-аргініну (у \%) до та після лікування на 5-ту добу експерименту. 


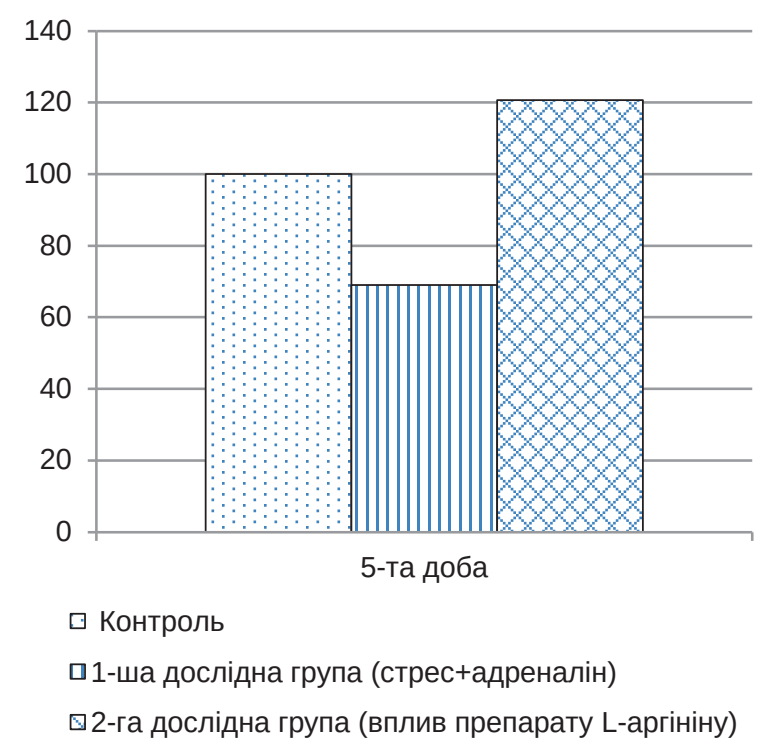

Рис. 2. Активність супероксиддисмутази в крові щурів при іммобілізаційному стресі та адреналіновому ушкодженні міокарда і вплив L-аргініну (у \%) до та після лікування на 5-ту добу експерименту.

Зокрема, рівень ДК підвищився на 125,45 \% $(p<0,05)$ проти контролю. У 2-й дослідній групі, яка поєднувала іммобілізаційний стрес і адреналінове ушкодження міокарда та введення L-аргініну, він знизився на 80,16 \% $(\mathrm{p}<0,05)$ на 5-ту добу порівняно 3 1-ю дослідною групою, що показано на рисунку 3.

Рівень МДА також зріс на 5-ту добу експерименту до лікування при коморбідній патології (іммобілізаційний стрес і адреналінове ушкодження міокарда) - на 118,93 \% $(p<0,05)$ порівняно $з$ контролем. Його зниження ми спостерігали на 5-ту добу після лікування L-аргініном при проведенні експерименту (іммобілізаційний стрес і адреналінове ушкодження міокарда) - на $42,26 \%(p<0,05)$ порівняно 3 1-ю дослідною групою (рис. 4), що вказує на його антиоксидантний вплив за умов поєднаної патології.

ВИСНОВКИ. Іммобілізаційний стрес та адреналінове ушкодження міокарда супроводжуються зниженням активності супероксиддисмутази і каталази в крові на 5-ту добу експерименту до лікування. Використання L-аргініну протягом 5-ти днів призводить до підвищення активності каталази на 107,2\% (p<0,05), супероксиддисмутази на $74,5 \%(p<0,05)$ відносно групи тварин з поєднаною патологією в експерименті (іммобілізаційний стрес та адреналінове ушкодження міокарда) до лікування, що свідчить про антиоксидантний вплив даного препарату. Проведені дослідження показали зростання на 5-ту добу експерименту рівня в крові дієнових кон'югатів (на 125,45 \%, р<0,05) і малонового діальдегіду (на 118,93 \%, р<0,05) проти контроль-

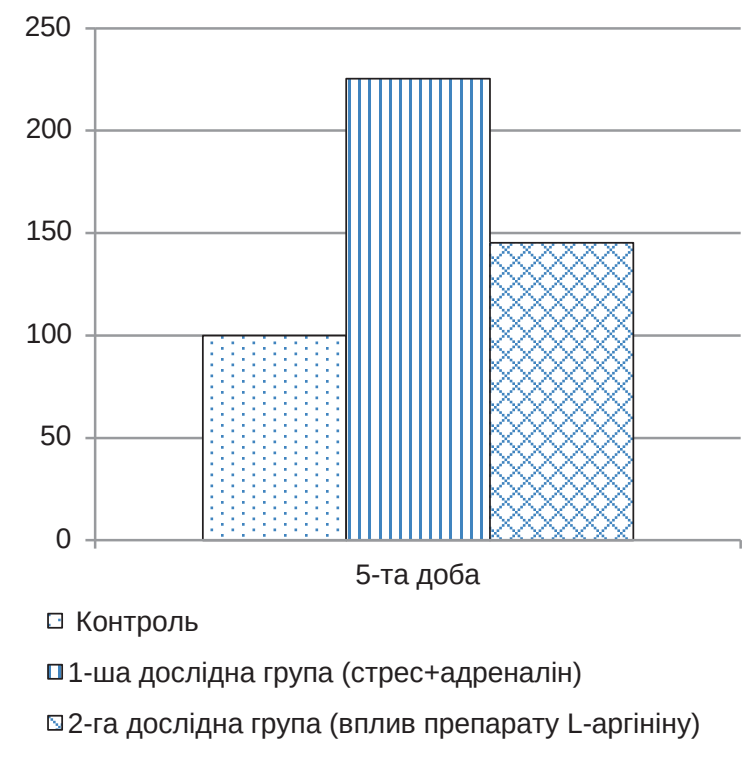

Рис. 3. Рівень дієнових кон'югатів у крові щурів при іммобілізаційному стресі та адреналіновому ушкодженні міокарда і вплив L-аргініну (у \%) до та після лікування на 5-ту добу експерименту.

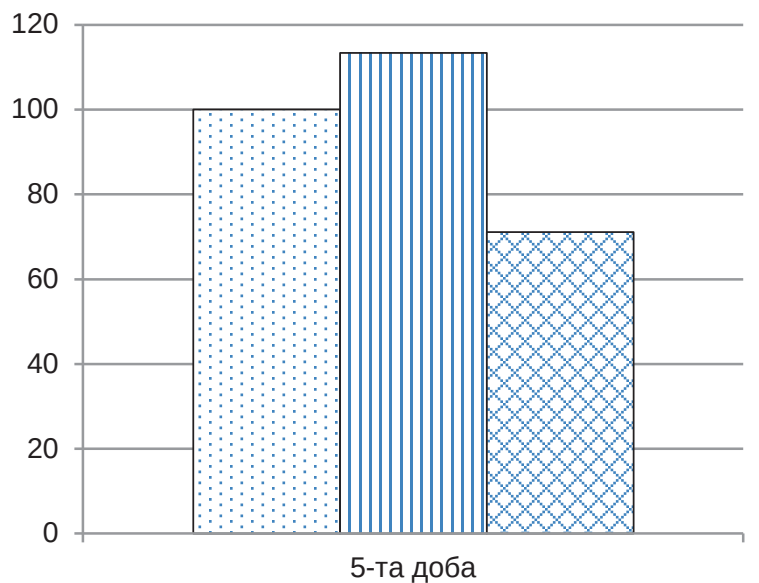

๑онтроль

口1-ша дослідна група (стрес+адреналін)

⿶2-га дослідна група (вплив препарату L-аргініну)

Рис. 4. Рівень малонового діальдегіду в крові щурів при іммобілізаційному стресі та адреналіновому ушкодженні міокарда і вплив L-аргініну (y \%) до та після лікування на 5-ту добу експерименту.

ної групи тварин до лікування. Застосування препарату L-аргініну протягом 5-ти днів знижує рівень дієнових кон'югатів на 80,16 \% $(p<0,05)$, малонового діальдегіду - на 42,26 \% $(p<0,05)$, що вказує на зменшення процесів пероксидного окиснення ліпідів.

Перспективи подальших досліджень. L-аргінін доцільно в подальшому і перспективно вивчати в експерименті та клініці з метою корекції метаболічних порушень за умов експериментального іммобілізаційного стресу й адреналінового ушкодження міокарда і розробки методичних рекомендацій. 


\section{СПИСОК ЛІТЕРАТУРИ}

1. Коптев М. М. Оцінка морфо--функціональних змін перисреричних відділів легені після впливу гострого іммобілізаційного стресу / М. М. Коптев // Актуальні проблеми сучасної медицини : Вісн. Укр. мед. стомат. акад. - 2013. - 13, № 4 (44). - С. 121-124.

2. Тимошенко А. В. Оцінка впливу гострого іммобілізаційного стресу на серце щура / А. В. Тимошенко, Д. О. Дягуленко, М. М. Коптев // Актуальні проблеми сучасної медицини : Вісн. Укр. мед. стомат. акад. 2014. - 14, № 4 (48). - С. 229-231.

3. Шкурупій О. А. Експериментальне обґрунтування розвитку некардіогенного набряку легень у хірургічних хворих при обмеженій руховій активності / О. А. Шкурупій // Вісн. проблем біології і медицини. 2015. - 2 (125), вип. 4. - С. 68-70.

4. Меерсон Ф. 3. Адаптация к стрессорным ситуациям и фиизическим нагрузкам / Ф. 3. Меерсон, М. Г. Пшенникова. - М. : Медицина, 1988. - 256 с.

5. Селье Г. Стресс без дистресса / Г. Селье. - М. : Медицина, 1980. - 180 с.

6. Радченко О. М. Адаптаційні реакції, їх значення у клініці внутрішніх хвороб : дис. ... д-ра мед. наук : 14.01.02 / Радченко Олена Мирославівна. - Львів, 2004. - 264 c.

7. Радченко О. М. Адаптаційні реакції в клініці внутрішніх хвороб : монографія / О. М. Радченко. Львів : Ліга-прес, 2004. - 230 с.

8. Маркова О. О. Міокардіодистрофрія і реактивність організму / О. О. Маркова. - Тернопіль : Укрмедкнига, 1998. - 152 c.
9. Böger R. H. Thepharmacodynamicsof L-arginine / R. H. Böger // J. Nutr. - 137. - 2007. - P. 1650-1655.

10. Chatterjee A. Endothelial nitric oxide (NO) and its pathophysiologic regulation / A. Chatterjee, J. D. Catravas // Vascul. Pharmacol. - 2008. - 49. - P. 134-140.

11. Бабушкина A. B. L-аргинин с точки зрения доказательной медицины / А. В. Бабушкина // Укр. мед. часоп. - 2009. - № 6 (74), XI-XII. - С. 43-48.

12. Метод определения активности каталазы / М. А. Королюк, Л. И. Иванова, И. Г. Майорова, В. Е. Токарев // Лаб. дело. - 1988. - № 1. - С. 16-19.

13. Гуревич В. С. Сравнительный анализ двух методов определения активности СОД / В. С. Гуревич, К. Н. Конторщиков, Л. В. Шатилина // Лаб. дело. 1990. - № 4. - С. 44-47.

14. Справочник по клинико-биохимической лабораторной диагностике : в 2 т. / под ред. В. С. Камышникова. - Минск : Беларусь, 2000. - 2. - С. 205-206.

15. Тимирбулатов Р. А. Метод повышения интенсивности свободнорадикального окисления липидсодержащих компонентов крови и его диагностическое значение / Р. А. Тимирбулатов, Е. И. Селезнев // Лаб. дело. - 1981. - № 4. - С. 209-211.

16. Горизонтов П. Д. Стресс и система крови / П. Д. Горизонтов, О. И. Белоусова, М. И. Фетодов. М. : Медицина, 1983. - 338 с.

17. Ткач. Є. І. Загальна теорія статистики / Є. І. Ткач, В. П. Сторожук. - К. : Центр учбової літератури, 2009. -440 C.

\section{REFERENCES}

1. Koptev, M.M. (2013). Otsinka morfo-funktsionalnykh zmin perypherychnykh viddiliv leheni pislia hostroho immobilizatsiinoho stresu [Evaluation of morpho-functional changes of peripheral lung organs after acute immobilization stress]. Aktualni problemy suchasnoi medytsyny: Visnyk Ukrainskoi medychoi stomatolohichnoi akademii Current Problems of Modern Medicine: Journal of the Ukrainian Medical Stomatological Academy, 13, 121-124. [in Ukrainian].

2. Tymoshenko, A.V., \& Diahulenko, D.O., \& Koptev, M.M. (2014). Otsinka vplyvu hostroho immobilizatsiinoho stresu na sertse shchura [Assessment of the effect of acute immobilization stress on the heart of a rat]. Aktualni problemy suchasnoi medytsyny: Visnyk Ukrainskoi medychoi stomatolohichnoi akademii - Current Problems of Modern Medicine: Journal of the Ukrainian Medical Stomatological Academy, 14, 229-231 [in Ukrainian].

3. Shkurupii, O.A. (2015). Eksperymentalne obhruntuvania rozvytky nekardiohennoho nabriaky lehen [Experimental study of the development of non-cardiogenic pulmonary edema in surgical patients with limited motor activity]. Visnyk Problem Biolohii I Medytsyny - Bulletin of Biology and Medicine, 4, 68-70 [in Ukrainian].
4. Meerson, F.Z., \& Pshennikova, M.G. (1988). Adaptatsiya $k$ stressornym situatsiyam i fizicheskim nagruzkam [Adaptation to stressful situations and physical loads]. Moscow: Meditsina [in Russian].

5. Selye, G. (1980). Stress bez stressa [Stress without distress]. Moscow: Meditsina [in Russian].

6. Radchenko, O.M. (2004). Adaptatsiini reaktsii, ikh znachennia v klinitsi vnutrishnikh khorob [Adaptation reactions, their significance in the clinic of internal diseases]. Doctor's thesis. Lviv [in Ukrainian].

7. Radchenko, O.M. (2004). Adaptatsiini reaktsii v klinitsi vnutrishnikh khorob [Adaptation reactions in the clinic of internal diseases]. Monograph. Lviv: Liha-press [in Ukrainian].

8. Markova, O.O. (1998). Miokardiodystrofiia i reaktyvnist orhanizmu [Myocardial dystrophy and reactivity of the organism]. Ternopil Ukrmedknyha [in Ukrainian].

9. Böger, R.H. (2007). The pharmacodynamics of L-arginine]. J. Nutr., 137, 1650-1655.

10. Chatterjee, A., \& Catravas, J.D. (2008). Endothelial nitric oxide (NO) and its pathophysiologic regulation. Vascul. Pharmacol., 49, 134-140.

11. Babushkina, A.V. (2009). L-arginin z tochki zreniya dokazatelnoy meditsiny [ $L$-arginine in terms of evidence- 
based medicine]. Ukrainskyi medychnyi chasopys - Ukrainian Medical Chronicle, 6, 43-48 [in Ukrainian].

12. Korolyuk, M.A., Ivanova, L.I., Mayorova, I.G., \& Tokarev, V.E. (1998). Metod opredeleniya aktivnosti katalazy [Method of determination of the activity of catalase]. Laboratornoye delo - Laboratory Business, 1, 16-19 [in Russian].

13. Gurevich, V.S., Kontorshchikov, K.N., \& Shatilina, L.V. (1990). Sravnitelnyy analiz dvukh metodov opredeleniya aktivnosti SOD [Comparative analysis of the method-determination of the activity of the SOD]. Laboratornoye delo - Laboratory Business, 4, 44-47 [in Russian].

14. Kamyshnikova, V.S. (2000). Spravochnik po kliniko-biokhimicheskoy laboratornoy diagnostike [Direc- tory for clinical and biochemical laboratory diagnostics. In two volumes]. Minsk: "Belarus" [in Russian].

15. Timirbulatov, R.A. (1988). Metod povysheniya intensivnosti SRO lipidsoderzhashchykh komponentov krovi i ego diagnosticheskoe znachenie [Method of increasing the intensity of SRO lipid - containing blood components and its diagnostic test]. Laboratornoye delo - Laboratory Business, 4, 209-211 [in Russian].

16. Gorizontov, P.D., Belousova, O.I., \& Fetodov, M.I. (1983). Stress i sistema krovi [Stress and blood system]. Moscow: Meditsina [in Russian].

17. Tkach, Ye.I. \& Storozhuk, V.P. (2009). Zahalna teoriia statystyky [The general theory of statistics]. Kyiv: Tsentr uchbovoi literatury [in Ukrainian].

\section{ВЛИЯНИЕ ПРЕПАРАТА Ц-АРГИНИНА НА ИЗМЕНЕНИЯ ПРОЦЕССОВ ПЕРЕКИСНОГО ОКИСЛЕНИЯ ЛИПИДОВ И АНТИОКСИДАНТНОЙ СИСТЕМЫ В КРОВИ В УСЛОВИЯХ КОМОРБИДНОЙ ПАТОЛОГИИ - ИММОБИЛИЗАЦИОННОГО СТРЕССА И АДРЕНАЛИНОВОГО ПОВРЕЖДЕНИЯ МИОКАРДА}

\section{Резюме}

Вступление. Активация адренергической и гипоталамо-гипофизарно-адреналовой систем приводит к возникновению стрессорной триады Селье, первым компонентом которой является гипертрофрия надпочечников с увеличением синтеза ними глюкокортикоидов и катехоламинов. Аргинин служит необходимым компонентом для синтеза белков и многих биологически важных молекул, таких, как орнитин, пролин, полиамины, креатин и агматин. Однако главная его роль в организме человека - быть субстратом для синтеза оксида азота.

Цель исследования - изучить влияние препарата L-аргинина на изменения процессов перекисного окисления липидов и антиоксидантной системы, возникающие в крови белых крыс под влиянием острого иммобилизационного стресса и адреналина.

Методы исследования. Опыт проводили на белых крысах-самцах линии Вистар массой 180-200 2, которые были разделены на три группы по 10 животных в каждой (две исследовательские и одну контрольную).

Результаты и обсуждение. Установлено, что в условиях сочетанной патологии (иммобилизационного стресса и адреналинового повреждения миокарда) до лечения $L$-аргинином активность в крови показателей антиоксидантной системы - каталазы и супероксиддисмутазы уменьшалась на 5-е сутки эксперимента. Было отмечено увеличение уровня продуктов перекисного окисления липидов - диеновых конъюгатов и малонового диальдегида против контроля. Использование L-аргинина в течение 5-ти дней привело к повышению активности каталазы (на 107,2 \%) и супероксиддисмутазы (на 74,5 \%) относительно группы животных с сочетанной патологией в эксперименте (иммобилизационным стрессом и адреналиновым повреждением миокарда) до лечения, что свидетельствует о антиоксидантном воздействии данного препарата. Применение $L$-аргинина в течение 5-ти дней снизило уровень диеновых конъюгатов (на 80,16 \%, р<0,05) и малонового диальдегида (на 42,26 \%, p<0,05), что указывает на уменьшение процессов перекисного окисления липидов.

Вывод. L-аргинин челесообразно в дальнейшем и перспективно изучать в эксперименте и клинике с целью коррекции метаболических нарушений в условиях экспериментального иммобилизационного стресса и адреналинового повреждения миокарда и разработки методических рекомендаций.

КЛЮЧЕВЫЕ СЛОВА: перекисное окисление липидов; антиоксидантная система; иммобилизационный стресс; адреналиновое повреждение миокарда; L-аргинин. 


\section{INFLUENCE OF L-ARGININ DRUGS ON THE CHANGE OF LIPID PEROXIDATION AND ANTIOXIDANT SYSTEMS IN BLOOD UNDER CONDITIONS OF COMBINATION PATHOLOGY - IMMOBILIZATIONAL STRESS AND ADRENALIN DAMAGE OF MYOCARDIUM}

\section{Summary}

Introduction. The activation of adrenergic and hypothalamic-pituitary-adrenal systems leads to the Selye stress triad, the first component of which is argenal gland hypertrophy and increased synthesis of glucocorticoids and catecholamines. Arginine is a necessary component for the synthesis of proteins and number of biologically important molecules, such as ornithine, proline, polyamines, creatine and agmatine. However, the main role of arginine in human body - to be a substrate nitrogen oxide synthesis.

The aim of the study - to learn the effect of L-arginine on changes in the processes of lipid peroxidation and antioxidant system in the blood of white rats under the influence of acute immobilization stress and adrenaline.

Research Methods. The experiment was carried out on white male rats of the Vistar line weighing 180-200 g, which were divided into 3 groups (two experimental and one control, 10 animals in each).

Results and Discussion. It was revealed that under conditions of combined pathology of immobilization stress and adrenal damage of myocardium before treatment with L-arginine, blood activity in the antioxidant system of catalase and superoxide dismutase decreased in the 5th day of the experiment. The increase of the products of $L P$-diene conjugates and malonic aldehyde was established. 5 days administration of $L$-arginine results in increased activity of CT (107.2\%) and SOD (74.5\%) in comparison with a group of animals with a combined pathology in the experiment (IS + AIM) prior to treatment, indicating the antioxidant effect of the drug. The use of L-arginine for 5 days reduced the content of diene conjugates by $80.16 \%(p<0.05)$ and MDA by $42.26 \%(p<0.05)$, indicating a decrease in lipid peroxidation processes.

Conclusion. Consequently, L-arginine is expedient in the future and perspective to be studied in the experiment and clinic in order to correct metabolic disorders in the conditions of experimental IC and APM and to develop methodological recommendations.

KEY WORDS: peroxide lipid oxidation and antioxidant system; immobilization stress; adrenal damage to the myocardium; L-arginine.

Отримано 02.08.18

Адреса для листування: М. С. Регеда, Львівський національний медичний університет імені Данила Галицького, вул. Пекарська, 69, Львів, 79010, Україна, e-mail: Ivivmedinst@gmail.com. 